\title{
All change at the water's edge: invasion by non-native riparian plants negatively impacts terrestrial invertebrates
}

\author{
Alex Seeney (D) S Sophie Eastwood · Zarah Pattison (1) - Nigel J. Willby (D) \\ Colin D. Bull
}

Received: 26 June 2018/ Accepted: 16 February 2019/Published online: 26 February 2019

(C) The Author(s) 2019

\begin{abstract}
Riparian zones are complex, dynamic habitats that play a critical role in river ecosystem functioning. Terrestrial invertebrates comprise much of the diversity found in riparian habitats and facilitate the transfer of energy between aquatic and terrestrial systems. However, the consequences for terrestrial invertebrates of invasion of riparian zones by invasive non-native plants (INNP) remain poorly understood. Responses of terrestrial macroinvertebrate morphospecies to invasion by two common INNP, Fallopia japonica (Japanese knotweed) and Impatiens glandulifera (Himalayan balsam) were assessed, relative to local environmental factors. Terrestrial invertebrates were collected from 20 sites on low order streams in June and August alongside data on physical attributes and land use. Greater cover of $F$. japonica and $I$. glandulifera cover reduced total invertebrate abundance and morphospecies diversity at the individual sample scale, whilst increasing spatial heterogeneity of invertebrates at the site scale. Impatiens glandulifera reduced morphospecies diversity at the site scale
\end{abstract}

Electronic supplementary material The online version of this article (https://doi.org/10.1007/s10530-019-01947-5) contains supplementary material, which is available to authorized users.

A. Seeney $(\bowtie) \cdot$ S. Eastwood $\cdot$ Z. Pattison ·

N. J. Willby · C. D. Bull

Biological and Environmental Sciences, University of

Stirling, Stirling FK9 4LA, UK

e-mail: alex.seeney@stir.ac.uk with increasing cover, but this was not observed for $F$. japonica. INNP affected terrestrial invertebrate morphospecies abundance and diversity, to a greater extent than prevailing environmental conditions. Our findings therefore offer support for managing riparian plant invasions to improve habitat heterogeneity, restore terrestrial invertebrate diversity and repair aquatic-terrestrial linkages.

Keywords Diversity $\cdot$ Fallopia japonica $\cdot$ Impatiens glandulifera $\cdot$ Invasive species $\cdot$ Morphospecies

\section{Introduction}

Terrestrial invasive non-native plants (INNP) represent over 300 of the established plant species in Europe (Keller et al. 2011). INNP are often associated with reductions in overall biodiversity (Barney et al. 2015), lower abundance of terrestrial primary consumers (McCary et al. 2016) and disruption of above and below-ground fungal communities (Pattison et al. 2016). Negative impacts on ecosystem services such as pollination and biomass production may also be associated with INNP (Hulme et al. 2013), alongside altered rates of erosion and water use compared to their native counterparts (Pejchar and Mooney 2009). Impacts on ecosystem services and biodiversity comprise some of the main criteria for listing a species as 
an invasive alien species (IAS) under EU regulation No. 1143/2014, which covers the prevention, management and spread of IAS (European Union 2014). INNP are also responsible for societal and economic losses, particularly when they colonise and disrupt agricultural land (Duncan et al. 2004), and often require costly investment to manage and/or repair ecological damage (such as flood damage following INNP colonisation) (Zavaleta 2000). Societal reactions to IAS may also depend on visible effects of visible invaders (Simberloff et al. 2013), which may hinder restoration efforts following colonisations by less prominent IAS.

The case for managing INNP is often built on evidence of their impacts, but such evidence can prove contentious. Conflicting arguments highlight potential benefits of INNP, such as use of Impatiens glandulifera (Himalayan balsam) by pollinators (Bartomeus et al. 2010), or use of INNP biomass as feed for livestock (Van Meerbeek et al. 2015), but also invoke detrimental legacy effects of INNP introductions (Iacarella et al. 2015; Corbin and D'Antonio 2017). Naturally dynamic systems are particularly prone to invasion by non-native species (Catford et al. 2012); riparian habitats, characterised by fluvial disturbance and exposed to waterborne transport of propagules, are thus amenable to invasions (Lawson et al. 2015). However, little is known about how invasion of riparian habitats by INNP impacts their terrestrial invertebrate communities.

Terrestrial invertebrates account for a large proportion of the diversity found within riparian ecosystems. They serve as indicators of environmental conditions (Gerlach et al. 2013), perform various key functions, including pollination of invasive and native plant species (Bartomeus et al. 2010), and mediate the transfer of energy between aquatic and terrestrial food webs (Gustafsson et al. 2014; Ramey and Richardson 2017). Riparian vegetation may significantly alter the allochthonous subsidy provided by terrestrial invertebrates (Allan et al. 2003), affecting the energy resources available to fish (Bridcut 2000; Baxter et al. 2005). However, terrestrial invertebrate communities are also influenced by other anthropogenic and environmental pressures, including land-use (Newbold et al. 2015), river discharge (Sinnadurai et al. 2016) and shading (Feld et al. 2018). These pressures may be further exacerbated by INNP, which thereby alter the structure and functioning of the ecosystems they invade (Ehrenfeld 2010). Gerber et al. (2008) demonstrated that riparian habitats invaded by Fallopia species harboured a reduced abundance and morphospecies richness of terrestrial invertebrates, whilst Ruckli et al. (2013) showed that $I$. glandulifera supported a higher abundance and species richness of gastropods compared to uninvaded plots. A range of responses by flower-visiting insect communities at sites colonised by INNP were demonstrated by Davis et al. (2018), including higher insect diversity associated with I. glandulifera and lower abundance of solitary bees and hoverflies associated with Heracleum mantegazzianum (giant hogweed).

Riparian zones support a disproportionately high species diversity (Gerber et al. 2008) and thus offer suitable habitats for studying the effects of INNP on invertebrate communities, especially as the structural complexity afforded by plant communities is an important mediator of predator-prey dynamics (Grutters et al. 2015). Fallopia japonica (Japanese knotweed) and I. glandulifera are two of the INNP species most commonly associated with riparian habitats in the northern hemisphere, the former being listed among the world's 100 worst invasive alien species (Lowe et al. 2000). Impatiens glandulifera was first introduced from the Himalayas in the early $1800 \mathrm{~s}$ (Perrins et al. 1993), and has subsequently become one of the most widespread invasive plants in the UK (Pattison et al. 2016) due to its ability to thrive in disturbed environments (Greenwood and Kuhn 2015; Greenwood et al. 2018). As an annual plant, $I$. glandulifera can affect riparian vegetation composition by displacing native ruderal species (Tanner et al. 2013), which combined with fluvial disturbance makes I. glandulifera a common and successful invader of riparian systems (Čuda et al. 2017). Native plant species are displaced via direct competition for resources, such as water and light, though displacement may also extend to competition for pollinators (Thijs et al. 2011). The invasive success of $I$. glandulifera is due to a combination of tolerance for a wide range of climates and soils (Chittka and Schurkens 2001), and an explosive seed dispersal system, which facilitates its spread throughout river corridors. Fallopia japonica is an herbaceous, perennial plant native to China, Japan, Korea and Taiwan, but which is now widely established in Europe following its introduction in the early nineteenth century (Beerling et al. 1994). It can recruit via several 
modes, including clonal, rhizomatous growth (Aguilera et al. 2009), and quickly forms monocultures, particularly in disturbed habitats. However, F. japonica is also able to spread via a seed bank, and can overwinter without any negative impact on germination success the following spring (Gowton et al. 2016). Similarly to $I$. glandulifera, $F$. japonica displaces native vegetation, thereby altering the composition of riparian plant communities, with consequences for aquatic and terrestrial invertebrates. Alongside normal modes of competition (e.g. shading, monopolisation of nutrients), $F$. japonica also excludes native plants via allelopathy (Siemens and Blossey 2007; Murrell et al. 2011).

INNP can impact native biota through a variety of different mechanisms (Vila et al. 2011) and to varying degrees depending on the taxonomic level studied (Pysek et al. 2012). The diversity of terrestrial invertebrate species and their functional significance makes them an excellent group for assessing the impacts of INNP in riparian systems. The aim of this study was to compare the effects of $F$. japonica and $I$. glandulifera on terrestrial invertebrate community composition, evaluating the relative effects of these two INNP species against those of other environmental factors, such as soil organic content and native plant community structure.

\section{Methods}

Study sites

Sites were located on low (1st to 4th) order streams in catchments across central and southern Scotland (Online Resource 1), providing a range of geographically and environmentally varied sampling locations (Online Resource 2). On each stream, a pair of control sites were located upstream from a pair of invaded sites containing established stands of either F. japonica or I. glandulifera, the sites in each control or invaded pair being separated by an average of $0.35 \mathrm{~km}$. Control sites were located on average between 0.6 and $2.9 \mathrm{~km}$ upstream from invaded sites, and sites were chosen where the focal INNPs had been established for at least a 10 year period. There were 20 study sites in total; four invaded by $F$. japonica and six invaded by $I$. glandulifera, and the two INNP species did not co-occur at any study sites. Sites were limited by the size of INNP stands present, and as such were standardised to a $20 \mathrm{~m}$ length of bank. Invaded sites were identified provisionally on the criteria that INNP coverage exceeded $50 \%$ of the vegetation cover on at least one bank, whilst other characteristics should as far as possible match those of upstream uninvaded sites (Sax et al. 2005). However in practice, INNP coverage fell below this threshold at some study sites.

Terrestrial invertebrate sampling and processing

Terrestrial invertebrates were collected using pitfall traps, each comprising a $500 \mathrm{ml}$ plastic pot $(10 \mathrm{~cm}$ diameter) with a screw-top lid. To reduce the risk of flooding, four drainage holes were added near the top of the trap, and a ceramic tile was placed over the top of each trap, acting as a rain shelter and allowing a small vertical gap between the trap and the tile for invertebrate access (Online Resource 4). To avoid catching non-target fauna, an $85 \mathrm{~mm}$ diameter hole was cut from the trap lid and replaced with heavy-duty garden mesh (mesh size $13 \mathrm{~mm}$ ). Traps were installed 3 weeks prior to the first proposed sampling session to minimise digging-in effects (Schirmel et al. 2010). At each site, 12 traps were installed at $75 \mathrm{~cm}$ intervals along a linear transect running parallel to the river and located in the middle of an invasive stand at invaded sites. Traps were installed approximately between 1 and $2 \mathrm{~m}$ horizontally from the water's edge (i.e. above the bankfull level) to minimise the risk of inundation by flood water. As traps were left collecting for 1-week periods, antifreeze (approximately $60 \mathrm{~mm}$ of $25 \%$ ethylene glycol) was used as a killing agent. Longer periods of trap exposure were rejected to reduce the risk of reduced trap catchability caused by evaporation of preservative (Schirmel et al. 2010). Sites were then sampled for 1 week during each of June and August to allow changes in invertebrate composition to be assessed in response to the summer peak of INNP growth. Upon collection, trap contents were preserved in the field with $70 \%$ industrial methylated spirits and invertebrates were thereafter assigned to morphospecies (Báldi 2003; Krell 2004) using light microscopy (up to $\times 64$ magnification). Parataxonomy and the use of morphospecies classifications was preferred to achieve accurate comprehensive estimates of terrestrial invertebrate diversity, whilst also minimising the risk of skewed estimates of individual abundance caused by errors in taxonomic identification 
(Oliver and Beattie 1996). Terrestrial invertebrate keys were used to guide the assignment of morphotypes (Chinery 1993; Tilling 2014), and guidance from experts was sought for the most commonly recorded groups (Diptera and Coleoptera) to ensure individuals were correctly partitioned into morphotypes.

\section{Physico-chemical variables}

Land use at each site was categorised at scales of both $5 \mathrm{~m}$ and $50 \mathrm{~m}$ from the water's edge based on a visual assessment and aerial photographs accessed via Google Earth, to give an estimate of the proportion of natural and artificial land use (as defined in the River Habitat Survey (Raven et al. 1998)). Site orientation (recorded as degrees from north) and site elevation were also obtained from Google Earth, and the total number of trees at each study site exceeding $5 \mathrm{~m}$ in height (henceforth tree density) was recorded in the field as a proxy for channel shading caused specifically by riparian tree cover.

Five soil cores $(6 \mathrm{~cm}$ depth, $4 \mathrm{~cm}$ diameter) were taken at each site, spread equidistantly along the pitfall trap transect. Loss on ignition (LOI) was used to measure soil organic matter content (Heiri et al. 2001). Soil samples were aggregated and air dried at $100{ }^{\circ} \mathrm{C}$ overnight in a furnace, ground using a pestle and mortar, and passed through a $2 \mathrm{~mm}$ sieve. They were then heated at $550{ }^{\circ} \mathrm{C}$ overnight to combust organic matter. Soil organic content was then defined as the change in mass before and after burning.

To quantify INNP cover, vegetation surveys were conducted during August to coincide with peak growing season. Using three transects running perpendicular to the channel, three $1 \mathrm{~m}^{2}$ quadrats were placed equidistantly on each transect between the foot and top of the bank containing pitfall traps, giving a total of nine quadrats on the bank (at seven sites it was not possible to place the full nine quadrats due to the narrowness of the riparian zone). The cover of all plants was estimated visually in each quadrat, the percentage covers of $F$. japonica and I. glandulifera in each quadrat were averaged separately over the bank containing the pitfall traps to provide an estimate of the cover of each INNP. Plants recorded in the vegetation surveys were identified to species with the aid of taxonomic keys (Rose and O'Reilly 2006; Poland and Clement 2009).
Invertebrate indices

Terrestrial invertebrate community morphospecies diversity was expressed using both the sample level alpha and site level gamma diversity, based on the full complement of morphospecies in each pitfall trap and at each site respectively. Total invertebrate abundance per pitfall trap was also calculated for each weekly sampling period.

The Bray-Curtis dissimilarity index was used to express spatial dissimilarity in terrestrial invertebrate communities, giving a measure of turnover between individual pitfall traps at a given site, based on morphospecies composition. To assess spatial dissimilarity, a series of pairwise Bray-Curtis dissimilarities was generated for each site for a given sampling month (comparing the first sample to each of the rest, then the second to the rest, etc.). The average value for each of these pairwise comparisons was calculated and used as a measure of dissimilarity between a specific sample and the remaining population of samples from that site. Higher values indicated greater turnover in composition between samples. Given that distance between pitfall traps affects the capture rates of ground-dwelling arthropods (Zhao et al. 2013), pairwise Bray-Curtis dissimilarities were weighted based on distances between pairs of traps.

Plant community indices

Plant community richness (excluding $F$. japonica and I. glandulifera) was expressed using Shannon's diversity index. Plant cover estimates were standardised to account for the number of quadrats sampled at each site.

Additionally, Ellenberg's indicator scores (Ellenberg 1986) were used to express the ecological attributes of the native plant community. Ellenberg's indicator scores are values assigned to vascular plant species for a range of environmental conditions including moisture, soil reaction and light regime (Schaffers and Sýkora 2000), which can be used to infer conditions at a site based upon the composition of the plant community.

\section{Statistical analysis}

Linear mixed effects models (LMMs) were used to investigate drivers of variation in the selected 
invertebrate metrics (response variables: Invertebrate morphospecies diversity based on Simpson's index, invertebrate spatial dissimilarity based on Bray-Curtis, total invertebrate abundance and invertebrate morphospecies gamma diversity). The finalised list of predictors was refined based on preliminary analysis-predictors were checked for collinearity after Zuur et al. (2010), model responses were assessed for normality, and normality of the model residuals was checked using normal probability plots. Final predictors included $F$. japonica cover, I. glandulifera cover, site elevation, mean Ellenberg indicator values for light (Ell-Light) and moisture (Ell-Moisture), tree density, percentage natural land use at the $50 \mathrm{~m}$ scale, soil organic matter content and native vegetation diversity using Shannon's index. River identity was treated as a random effect, and models were run using a nested random effect of study site within river (Zuur et al. 2009). However, since this nested component accounted for $<10 \%$ of the variation it was removed from the model following rules of parsimony, leaving only river as a random effect in the final models. Residuals were checked for normality and heteroscedasticity (Zuur et al. 2010).

To test for an effect of sampling month, each model was run with month as a fixed effect. If this model output showed evidence of a significant month effect $(p<0.05)$, sampling month was then included as an interaction term to determine whether predictors had month-dependent effects. However, there was no evidence of any temporal dependency in the measured responses. Prior to modelling, predictors were scaled to one standard deviation to allow their effect sizes to be directly compared. All possible combinations of predictors were identified using the "dredge" function in MuMIn (Barton 2017). Models were then ranked by corrected Akaike information criterion (AICc) to account for small sample sizes. To identify the top set of models, a threshold of $\triangle \mathrm{AICc}<2$ was set (Burnham and Anderson 2002). From this top set, a fully averaged model was chosen for interpretation of coefficients (Barton 2017). To assess variation explained solely by the fixed effects, as well as variation explained by both the fixed and random effects together, both marginal and conditional $\mathrm{R}^{2}$ values are reported for each model (Nakagawa et al. 2013).

Morphospecies characteristic of invaded and uninvaded sites were identified using indicator species analysis (IndVal; Dufrêne and Legendre 1997) applied to the morphospecies abundance data at the individual trap level for all pairs of invaded and uninvaded sites. The indicator value assesses the specificity and fidelity of terrestrial morphospecies for invaded and uninvaded sites. The index ranges from $0 \%$ (no presence in a survey group), to $100 \%$ (present in only one group, and in all samples within that group). The significance of these values was tested using a Monte Carlo randomisation procedure (Dufrêne and Legendre 1997).

All statistical analyses were conducted using $\mathrm{R}$ 3.4.3 ( $\mathrm{R}$ Core Team 2017), with the additional packages vegan (Oksanen et al. 2017), reshape2 (Wickham 2007), labdsv (Roberts 2016), lme4 (Bates et al. 2015), lmerTest (Kuznetsova et al. 2016), effects (Fox 2003), MuMIn (Barton 2017) and r2glmm (Jaeger 2017).

\section{Results}

Across all study sites, individual pitfall traps contained an average of 100 individuals, representing an average of 11 morphospecies per trap and 32 morphospecies per site. The most common taxonomic groupings (by abundance) were Acari (25\%) and Coleoptera (24\%), followed by Diptera (13\%) and Collembola (12\%). The remaining individuals comprised a mix of winged individuals such as Hemiptera and Hymenoptera, the lower catch rate of these taxa being typical of pitfall trapping studies (Schirmel et al. 2010).

The top set of models (Online Resource 3) with $\Delta \mathrm{AICc}<2$ are shown in Table 1 . The relative variable importance, marginal $\left(\mathrm{R}^{2} \mathrm{~m}\right)$ and conditional $\left(\mathrm{R}^{2} \mathrm{c}\right)$ values are also shown (Table 1$)$.

Invertebrate morphospecies Simpson's diversity

Terrestrial invertebrate morphospecies diversity was negatively associated with the mean Ellenberg Indicator value for light (Fig. 1a) and with the cover of both INNP species (Figs. 1a and 2a). The largest effect sizes were associated with $F$. japonica and I. glandulifera cover, and these differed only marginally. 
Table 1 The best, fully-averaged models for models with $\Delta \mathrm{AICc}<2$. Relative variable importance is given in brackets, followed by marginal $\left(\mathrm{R}^{2} \mathrm{~m}\right)$ and conditional $\left(\mathrm{R}^{2} \mathrm{c}\right)$ values

\begin{tabular}{|c|c|c|c|}
\hline Response & Model parameters & $\mathrm{R}^{2} \mathrm{~m}$ & $\mathrm{R}^{2} \mathrm{c}$ \\
\hline $\begin{array}{r}\text { Simpson's } \\
\text { diversity }\end{array}$ & $\begin{array}{l}\text { I. glandulifera cover }(1)+F \text {. japonica cover }(1)+\text { Ell-Light }(1)+\text { native plant diversity } \\
(0.40)+\text { tree density }(0.21)+\text { soil organic content }(0.13)+\text { Ell-Moisture }(0.11)+\text { natural land } \\
\text { use at } 50 \mathrm{~m}(0.09)\end{array}$ & 0.17 & 0.31 \\
\hline $\begin{array}{l}\text { Total } \\
\text { abundance }\end{array}$ & $\begin{array}{l}\text { I. glandulifera cover }(1)+F \text {. japonica cover }(1)+\text { Ell-Light }(1)+\text { native plant diversity } \\
(0.49)+\text { soil organic content }(0.38)+\text { month }(0.36)+\text { site elevation }(0.22)+\text { tree density }(0.06)\end{array}$ & 0.23 & 0.34 \\
\hline $\begin{array}{l}\text { Spatial } \\
\text { dissimilarity }\end{array}$ & $\begin{array}{l}\text { I. glandulifera cover }(1)+F \text {. japonica cover }(1)+\text { Ell-Light }(1)+\text { soil organic content } \\
(0.66)+\text { month }(0.63)+\text { tree density }(0.49)+\text { Ell-Moisture }(0.49)+\text { native plant diversity } \\
(0.12)+\text { natural land use at } 50 \mathrm{~m}(0.08)\end{array}$ & 0.17 & 0.17 \\
\hline $\begin{array}{l}\text { Gamma } \\
\text { diversity }\end{array}$ & $\begin{array}{l}\text { I. glandulifera cover }(1)+\text { Ell-Moisture }(1)+\text { soil organic content }(1)+F \text {. japonica cover } \\
(0.28)+\text { tree density }(0.23)\end{array}$ & 0.39 & 0.50 \\
\hline
\end{tabular}

Total invertebrate abundance

Total abundance of terrestrial invertebrates was negatively associated with the mean Ellenberg Indicator value for light (Fig. 1b) and with the cover of both INNP (Figs. $1 \mathrm{~b}$ and $2 \mathrm{~b}$ ). Impatiens glandulifera cover had the largest effect size $(-18.36)$, marginally exceeding that of $F$. japonica.

Invertebrate spatial dissimilarity

Terrestrial invertebrate spatial dissimilarity between samples at a site was positively associated with the mean Ellenberg Indicator value for light (Fig. 1c) and with the cover of both INNP species (Figs. 1c and 2c). Fallopia japonica cover had the strongest overall effect (0.02).

\section{Invertebrate morphospecies gamma diversity}

Overall, gamma diversity of terrestrial invertebrates was positively associated with soil organic content and the mean Ellenberg Indicator value for moisture (Fig. 1d) and negatively associated with I. glandulifera cover (Figs. 1d and 2d). Impatiens glandulifera cover had the greatest overall effect $(-0.07)$, followed by the mean Ellenberg Indicator value for moisture (0.05). Fallopia japonica had no detectable effect and there was no evidence of any temporal dependency in the response.
Indicator species

A larger number of terrestrial invertebrate morphospecies were significantly associated with uninvaded sites compared to invaded sites (Table 2). Twenty invertebrate morphospecies were significantly associated with uninvaded sites, compared to eight at invaded sites. The strongest indicators of sites invaded by both $I$. glandulifera and F. japonica were morphospecies belonging to the Acari. Uninvaded sites were strongly characterised by members of the Coleoptera and Diptera, alongside other morphospecies of the Acari subclass.

\section{Discussion}

Invertebrate morphospecies Simpson's diversity and abundance

Our results indicate that the focal INNP species reduced the diversity and abundance of terrestrial invertebrates at heavily invaded sites. These findings offer support for similar studies reporting reductions in abundance and taxonomic richness in response to INNP (Gerber et al. 2008; Litt et al. 2014). Invasions by INNP can disrupt linkages between above and below-ground communities via changes to soil chemistry (Weidenhamer and Callaway 2010) and to resources entering the soil (Tanner et al. 2013). Lower community functional diversity and redundancy associated with INNP (Kominoski et al. 2013) can alter both the chemical composition and range of 

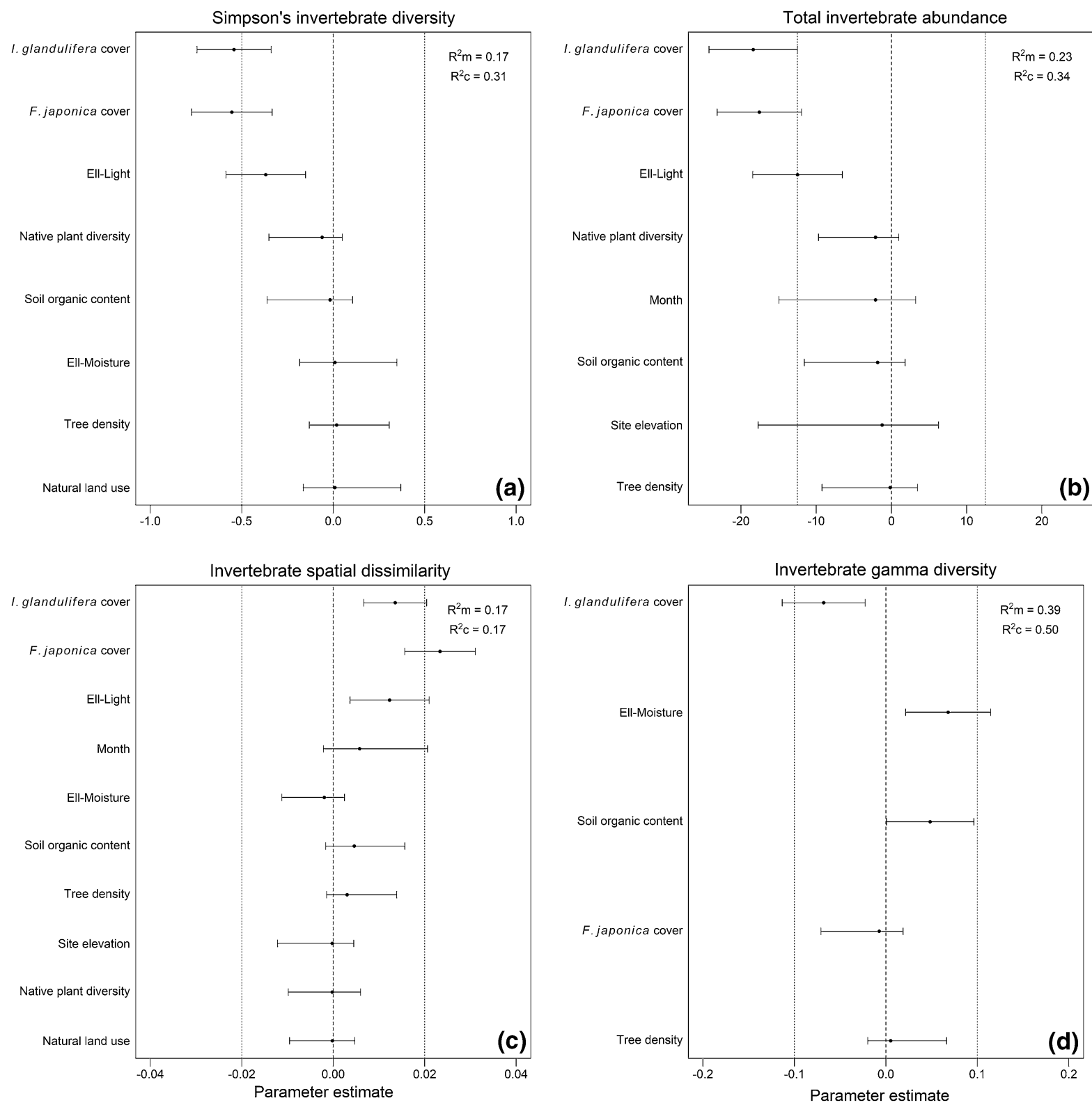

Fig. 1 Full, model-averaged parameter estimates $\pm 95 \%$ confidence intervals. Modelled responses were a Simpson's invertebrate diversity, b total invertebrate abundance, c spatial

degradability of leaf litter, eliciting negative responses in both above and below-ground invertebrate communities through poorer microhabitat structure and persistence (Scherber et al. 2010; Lecerf et al. 2011). In our study, both $F$. japonica cover and I. glandulifera cover showed strong negative associations with Simpson's invertebrate diversity and total invertebrate abundance compared to other environmental

dissimilarity and $\mathbf{d}$ invertebrate gamma diversity. Marginal $\left(\mathrm{R}^{2} \mathrm{~m}\right)$ and conditional $\left(\mathrm{R}^{2} \mathrm{c}\right)$ values are given

variables, in both sampling months. This supports the ability of INNP to impose structural changes on riparian habitats during their period of peak biomass (Pattison et al. 2017; Greenwood et al. 2018), as well as during the preceding months when INNP stands are developing.

Loss of native plant species from invaded sites may deplete invertebrate assemblages that specialise on 

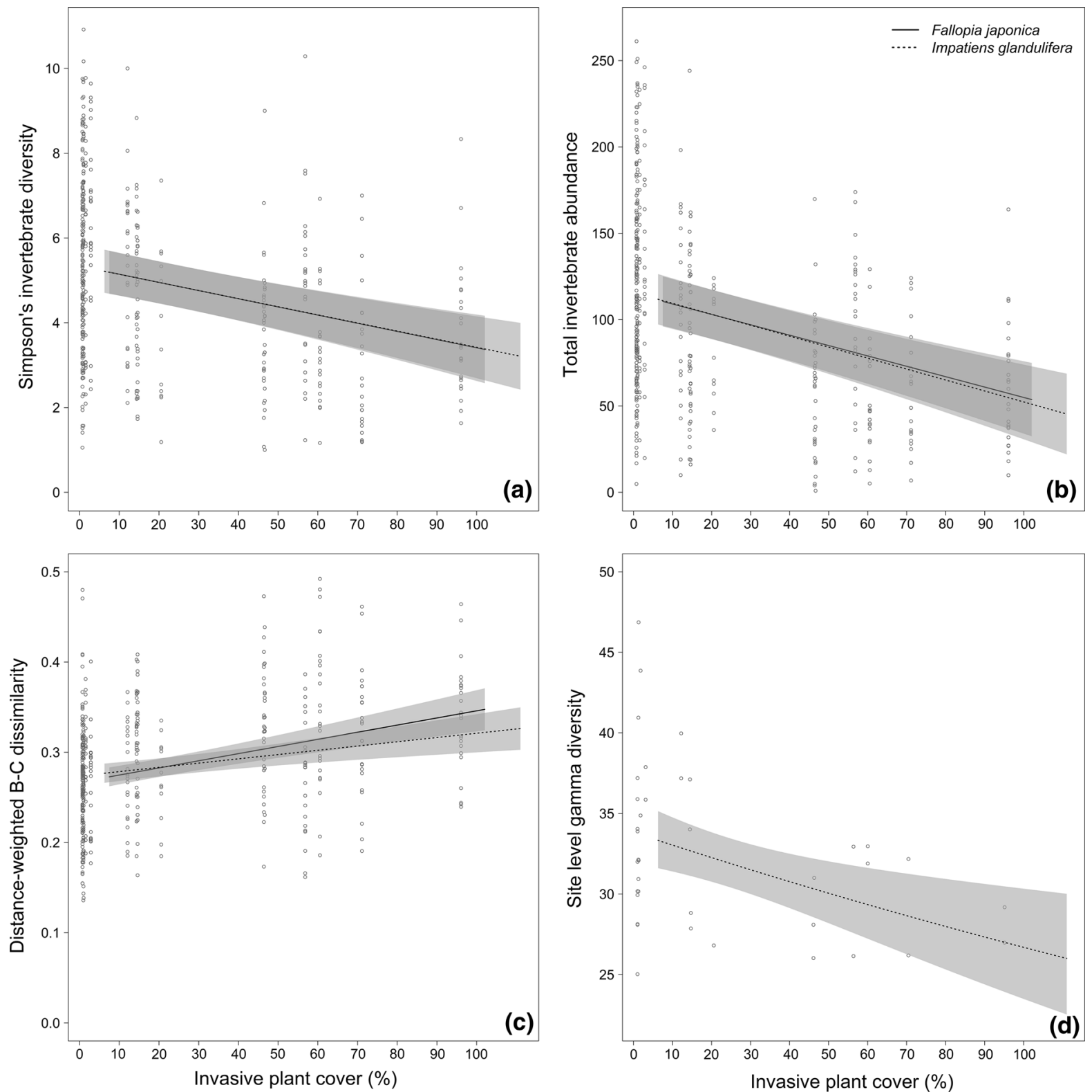

Fig. 2 Full model predicted values (shaded polygon shows \pm 95\% confidence intervals) plotted over raw data from the LMM analyses of a Simpson's invertebrate diversity, b total

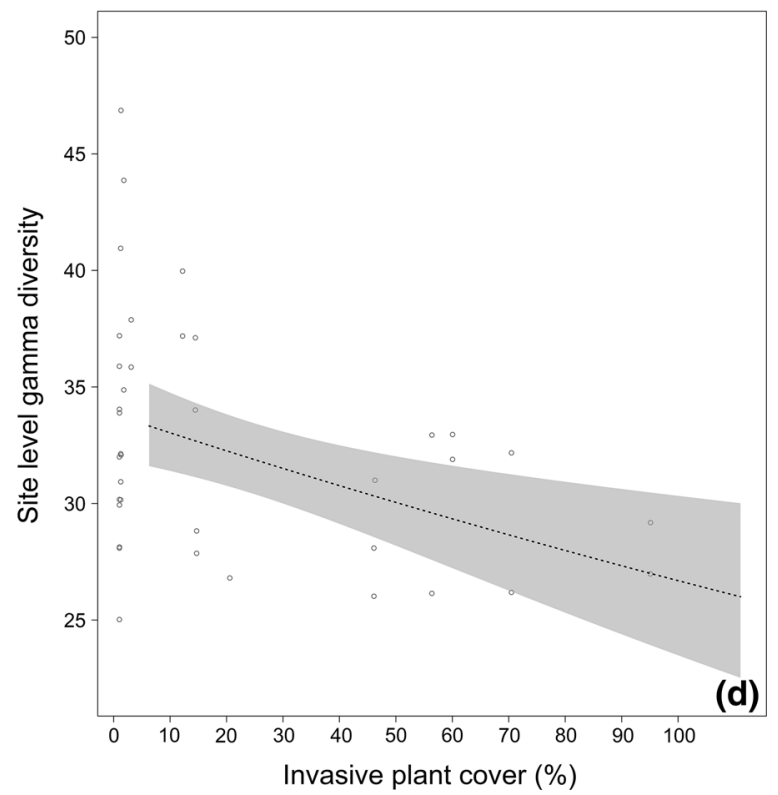

invertebrate abundance, $\mathbf{c}$ spatial dissimilarity and $\mathbf{d}$ invertebrate gamma diversity, all plotted against invasive plant cover

those plants or their architectural properties, causing an overall reduction in the diversity and abundance of invertebrate morphospecies (Reid and Hochuli 2007). In the absence of significant relationships between physico-chemical variables and terrestrial invertebrates, it is likely that the main factors driving invertebrate diversity and abundance are indeed

reductions in habitat complexity and resource availability, caused by either $F$. japonica or I. glandulifera.

Both invertebrate morphospecies diversity and abundance were negatively associated with Ell-Light, implying either that plants preferring higher light levels support a smaller number of fewer invertebrate morphospecies, or that invertebrates generally prefer more shaded conditions. A relatively open canopy 
Table 2 Significant indicator morphospecies ((1) indicates a larval stage) for invaded and uninvaded sites (invaded sites split by Impatiens glandulifera and Fallopia japonica)

Observed Indicator Value shows the indicator value for each species $(0=$ no fidelity or specificity; $100=$ complete fidelity and specificity). Asterisks indicate the probability of that Indicator Value occurring by chance based on permutation tests $(* * *<0.001, * *<0.01$, $*<0.05)$

\begin{tabular}{|c|c|c|}
\hline Site type & Morphospecies & Observed indicator value \\
\hline \multirow[t]{6}{*}{ Invaded by $I$. glandulifera } & Acari $\mathrm{B} * *$ & 31.7 \\
\hline & Oligochaeta** & 16.7 \\
\hline & Coleoptera (1) $\mathrm{K}^{*}$ & 6.8 \\
\hline & Chilopoda** & 4.6 \\
\hline & Diptera (1) $E^{*}$ & 4.6 \\
\hline & Gastropoda $C^{*}$ & 2.7 \\
\hline \multirow[t]{2}{*}{ Invaded by $F$. japonica } & Acari E*** & 40.2 \\
\hline & Diptera (l) $\mathrm{G}^{*}$ & 5.8 \\
\hline \multirow[t]{20}{*}{ Uninvaded } & Collembola*** & 38.2 \\
\hline & Diptera $\mathrm{C}^{* * *}$ & 38.2 \\
\hline & Coleoptera A*** & 35.9 \\
\hline & Acari D* & 25.5 \\
\hline & Opiliones** & 24.5 \\
\hline & Araneae A* & 24.3 \\
\hline & Coleoptera $E^{* *}$ & 23.6 \\
\hline & Coleoptera (1) G*** & 21.1 \\
\hline & Acari $\mathrm{A}^{* *}$ & 20.4 \\
\hline & Coleoptera $\mathrm{F}^{* * * *}$ & 20.1 \\
\hline & Hymenoptera D* & 14.7 \\
\hline & Acari C* & 14.5 \\
\hline & Isopoda* & 11.2 \\
\hline & Coleoptera B** & 11.0 \\
\hline & Coleoptera S* & 8.9 \\
\hline & Hymenoptera E** & 8.2 \\
\hline & Acari $\mathrm{G}^{*}$ & 6.9 \\
\hline & Diptera $\mathrm{Q}^{* *}$ & 5.9 \\
\hline & Hemiptera $\mathrm{C}^{*}$ & 5.0 \\
\hline & Diptera D* & 2.9 \\
\hline
\end{tabular}

providing minimal shade at the ground level would offer relatively little shelter for invertebrates that favour a dense, structurally complex habitat (Warfe and Barmuta 2004), and could reduce the abundance of terrestrial arthropods that favour shaded habitats (Greenberg et al. 2000).

Invertebrate spatial dissimilarity

Terrestrial invertebrate community composition was more dissimilar at heavily invaded sites for both $F$. japonica and I. glandulifera, suggesting that more heterogeneous invertebrate communities are associated with high levels of invasive cover. It is possible that INNP will benefit some invertebrate consumers, as some non-native invasive plants (including $F$. japonica (Lecerf et al. 2007)) contain higher foliar concentrations of nitrogen and phosphorus, as well as offering larger leaf area ratios, offering higher quality litter and greater microhabitat surface area than their native counterparts (Wardle et al. 2011). This is supported by the association of the saprophagous Fanniidae and Mycetophilidae families (Diptera (1) E and Diptera (1) G in Table 2, respectively) of Diptera larvae with invaded sites, indicating the presence of abundant decaying plant material. However, the negative associations between INNP cover and invertebrate diversity and abundance suggest that although both $F$. japonica cover and I. glandulifera were associated with a more heterogeneous fauna, this is at the expense of invertebrate diversity and abundance overall. 
Spatial dissimilarity within biological assemblages is often considered a desirable attribute (Swan and Brown 2017). However, such dissimilarity can also be an artefact of reduced morphospecies abundance and diversity. For example, if those invertebrates remaining in heavily invaded areas are patchily distributed, this will generate spatially heterogeneous but impoverished communities, as indicated by a reduction in the number of morphospecies associated with invaded sites in this study. This could suggest that increased heterogeneity between individual traps may arise sue to a loss of morphospecies, but this was not directly tested in this study. It is also possible that heterogeneity in variation at the individual trap scale at sites with lower INNP cover may directly affect invertebrate diversity, though this was not tested by this study.

Invertebrate community composition was also more dissimilar at sites with plant communities associated with higher light levels. Given that higher densities and diversity of invertebrates were associated with plants indicative of more shaded conditions, it is likely that the increased heterogeneity of assemblages in well-lit environments is also an artefact of the reduced richness and abundance of invertebrates, suggesting that sites with lower Ell-Light values support shade-tolerant plant species, which may offer invertebrates better quality habitat and resources.

Invertebrate morphospecies gamma diversity

Impatiens glandulifera cover showed a strong negative association with site level gamma diversity of terrestrial invertebrates. By contrast, the effect of $F$. japonica cover was not significant. There were positive associations between Ell-Moisture and soil organic content and invertebrate gamma diversity, but the large negative effect size of I. glandulifera outweighed any positive effects of environmental variables at the site scale.

INNP can alter ecosystem structure and functioning through changes to the local microclimate, resulting in changes to food resources and the structure of terrestrial invertebrate communities (Kappes et al. 2007). This would be reflected by an overall change in diversity at the site level, as a heavily invaded riparian zone would likely support a greatly altered terrestrial invertebrate community (Pysek et al. 2012). This is supported in part by the reduced number of indicator morphospecies associated with both I. glandulifera and $F$. japonica invaded sites, compared to uninvaded sites, indicating changes in morphospecies community composition. More morphospecies were indicative of sites invaded by $I$. glandulifera than $F$. japonica, suggesting that environmental conditions at $F$. japonica sites are more prohibitive to invertebrates. The morphospecies most indicative of uninvaded sites included Collembola and taxa from the Dipteran Phoridae family (Diptera C in Table 2) and Coleopteran Staphylinidae family (Coleoptera A in Table 2). Since beetles of these families favour decaying organic matter, this supports the suggestion that increased litter diversity fosters invertebrate diversity (Scherber et al. 2010; Lecerf et al. 2011). Acari were most strongly indicative of both types of invaded sites, which is unsurprising given their generalist tendencies and reputation for colonising most aquatic and terrestrial habitats by exploiting a wide range of resources (Vacante 2016). Positive associations were found between Ell-Moisture, soil organic content and invertebrate gamma diversity. Members of the Collembola, Oligochaeta and Diptera have all been shown to decline in abundance with reduced soil moisture (Hodkinson and Jackson 2005), while Santorufo et al. (2012) found that invertebrates were more abundant and diverse in soils with higher organic content and moisture.

Whilst the use of morphospecies in place of species level identification is well reported and defended (Oliver and Beattie 1996; Krell 2004), it would be valuable to incorporate measures of resource utilisation, foraging styles and microhabitat use (Ramey and Richardson 2017) into future studies to better understand the interactions between invertebrate taxa in riparian systems and to identify why some taxa are more sensitive to invasion. For example, taxonspecific reactions have been demonstrated in response to I. glandulifera invasion, which is able to modify the local microclimate, increasing local soil moisture and temperature, thereby promoting an increase in the abundance and diversity of gastropods (Ruckli et al. 2013) and Acari (Rusterholz et al. 2014). This study took place during the most active phase of the growing season when INNP are at their maximum extent and it would be valuable to determine if the observed effects are perpetuated after dieback. However, the unpredictability of river water levels due to flooding will constrain the effectiveness of pitfall trapping during autumn and winter. 


\section{Conclusions}

Overall, INNP were associated with reduced terrestrial invertebrate morphospecies abundance and both alpha (sample level) and gamma (site level) diversity. This indicates that their association with increased spatial dissimilarity in assemblages is unlikely to be beneficial, and the relationship between morphospecies richness and spatial dissimilarity may merit further investigation. INNP species had a stronger effect than local environmental conditions, demonstrating their ability to influence the ecosystems they invade, with impacts extending beyond the immediate plant community. It is evident that INNP can have measurable and significant impacts on these communities, which may ultimately affect energy transfer and other linkages between terrestrial and aquatic systems across a range of trophic levels.

Acknowledgements We gratefully acknowledge financial support for this study from Scottish Natural Heritage and the useful advice and direction provided by Phil Boon. Thanks to John Walters and Tony Irwin for their assistance with morphospecies identification. The authors declare they have no conflict of interest regarding this manuscript.

Open Access This article is distributed under the terms of the Creative Commons Attribution 4.0 International License (http:// creativecommons.org/licenses/by/4.0/), which permits unrestricted use, distribution, and reproduction in any medium, provided you give appropriate credit to the original author(s) and the source, provide a link to the Creative Commons license, and indicate if changes were made.

Authors' Contributions All authors conceived the ideas, designed the methodology and participated in data collection; AS, SE and ZP analysed the data; AS led the writing of the manuscript. All authors contributed critically to the drafts and gave final approval for publication.

\section{References}

Aguilera AG, Alpert P, Dukes JS, Harrington R (2009) Impacts of the invasive plant Fallopia japonica (Houtt.) on plant communities and ecosystem processes. Biol Invasions 12:1243-1252. https://doi.org/10.1007/s10530-009-9543-Z

Allan JD, Wipfli MS, Caouette JP, Prussian A, Rodgers J (2003) Influence of streamside vegetation on inputs of terrestrial invertebrates to salmonid food webs. Can J Fish Aquat Sci 60:309-320. https://doi.org/10.1139/f03-019

Báldi A (2003) Using higher taxa as surrogates of species richness: a study based on 3700 Coleoptera, Diptera, and
Acari species in Central-Hungarian reserves. Basic Appl Ecol 4:589-593. https://doi.org/10.1078/1439-1791-00193

Barney JN, Tekiela DR, Barrios-Garcia MN, Dimarco RD, Hufbauer RA, Leipzig-Scott P, Nunez MA, Pauchard A, Pysek P, Vitkova M, Maxwell BD (2015) Global invader impact network (GIIN): toward standardized evaluation of the ecological impacts of invasive plants. Ecol Evol 5:2878-2889. https://doi.org/10.1002/ece3.1551

Bartomeus I, Vilà M, Steffan-Dewenter I (2010) Combined effects of Impatiens glandulifera invasion and landscape structure on native plant pollination. J Ecol 98:440-450. https://doi.org/10.1111/j.1365-2745.2009.01629.x

Barton K (2017) MuMIn: multi-model inference. R package version 1.40.0. https://CRAN.R-project.org/package= MuMIn. Accessed Dec 2018

Bates D, Maechler M, Bolker B, Walker S (2015) Fitting linear mixed-effects models using lme4. J Stat Softw 67:1-48. https://doi.org/10.18637/jss.v067.i01

Baxter CV, Fausch KD, Carl Saunders W (2005) Tangled webs: reciprocal flows of invertebrate prey link streams and riparian zones. Freshw Biol 50:201-220. https://doi.org/ 10.1111/j.1365-2427.2004.01328.x

Beerling DJ, Bailey JP, Conolly AP (1994) Fallopia japonica (Houtt.) ronse decraene. J Ecol 82:959. https://doi.org/10. 2307/2261459

Bridcut EE (2000) A study of terrestrial and aerial macroinvertebrates on river banks and their contribution to drifting fauna and salmonid diets in a Scottish catchment. Hydrobiologia 427:83-100. https://doi.org/10.1023/a: 1003927331472

Burnham KKP, Anderson DRD (2002) Model selection and multimodel inference: a practical information-theoretic approach, 2nd edn. Springer, London

Catford JA, Daehler CC, Murphy HT, Sheppard AW, Hardesty BD, Westcott DA, Rejmánek M, Bellingham PJ, Pergl J, Horvitz CC, Hulme PE (2012) The intermediate disturbance hypothesis and plant invasions: implications for species richness and management. Perspect Plant Ecol Evol Syst 14:231-241. https://doi.org/10.1016/j.ppees. 2011.12.002

Chinery M (1993) Collins field guide to the insects of Britain and Northern Europe, 3rd edn. Harper Collins, New York City

Chittka L, Schurkens S (2001) Successful invasion of a floral market. Nature 411:653. https://doi.org/10.1038/35079676

Corbin JD, D'Antonio CM (2017) Gone but not forgotten? Invasive plants' legacies on community and ecosystem properties. Invasive Plant Sci Manag 5:117-124. https:// doi.org/10.1614/ipsm-d-11-00005.1

Čuda J, Rumlerová Z, Brůna J, Skálová H, Pyšek P, Rejmanek M (2017) Floods affect the abundance of invasive Impatiens glandulifera and its spread from river corridors. Divers Distrib 23:1-13. https://doi.org/10.1111/ddi.12524

Davis ES, Kelly R, Maggs CA, Stout JC (2018) Contrasting impacts of highly invasive plant species on flower-visiting insect communities. Biodivers Conserv 27:2069-2085. https://doi.org/10.1007/s10531-018-1525-y

Dufrêne M, Legendre P (1997) Species assemblages and indicator species: the need for a flexible asymmetrical approach. Ecol Monogr 67:345-366. https://doi.org/10.1890/00129615(1997)067\%5b0345:SAAIST\%5d2.0.CO;2 
Duncan CA, Jachetta JJ, Brown ML, Carrithers VF, Clark JK, Ditomaso JM, Lym RG, McDaniel KC, Renz MJ, Rice PM (2004) Assessing the economic, environmental, and societal losses from invasive plants on rangeland and wildlands. Weed Technol 18:1411-1416

Ehrenfeld JG (2010) Ecosystem consequences of biological invasions. Annu Rev Ecol Evol Syst 41:59-80. https://doi. org/10.1146/annurev-ecolsys-102209-144650

Ellenberg H (1986) Vegetation Mitteleuropas mit den Alpen in ökologischer Sicht, 4th edn. Verlag Eugen Ulmer, Stuttgart

European Union (2014) Regulation (EU) No 1143/2014 of the European Parliament and of the Council of 22 October 2014 on the prevention and management of the introduction and spread of invasive alien species

Feld CK, Fernandes MR, Ferreira MT, Hering D, Ormerod SJ, Venohr M, Gutierrez-Canovas C (2018) Evaluating riparian solutions to multiple stressor problems in river ecosystems - a conceptual study. Water Res 139:381-394. https://doi.org/10.1016/j.watres.2018.04.014

Fox J (2003) Effect displays in R for generalised linear models. J Stat Softw 8:1-27. https://doi.org/10.18637/jss.v008.i15

Gerber E, Krebs C, Murrell C, Moretti M, Rocklin R, Schaffner U (2008) Exotic invasive knotweeds (Fallopia spp.) negatively affect native plant and invertebrate assemblages in European riparian habitats. Biol Conserv 141:646-654. https://doi.org/10.1016/j.biocon.2007.12.009

Gerlach J, Samways M, Pryke J (2013) Terrestrial invertebrates as bioindicators: an overview of available taxonomic groups. J Insect Conserv 17:831-850. https://doi.org/10. 1007/s10841-013-9565-9

Gowton C, Budsock A, Matlaga D (2016) Influence of disturbance on Japanese knotweed (Fallopia japonica) stem and rhizome fragment recruitment success within riparian forest understory. Nat Areas J 36:259-267. https://doi.org/10. 3375/043.036.0306

Greenberg R, Bichier P, Angon AC, MacVean C, Perez R, Cano $E$ (2000) The impact of avian insectivory on arthropods and leaf damage in some Guatemalan coffee plantations. Ecology 81:1750-1755. https://doi.org/10.2307/177321

Greenwood P, Kuhn NJ (2015) The annual invasive plant, Impatiens glandulifera (Himalayan Balsam) as a trigger for high-magnitude soil erosion in temperate river systems. Geophys Res Abstr 17:1

Greenwood P, Baumann P, Pulley S, Kuhn NJ (2018) The invasive alien plant, Impatiens glandulifera (Himalayan Balsam), and increased soil erosion: causation or association? Case studies from a river system in Switzerland and the UK. J Soils Sedim 18:3463. https://doi.org/10.1007/ s11368-018-2041-0

Grutters BM, Pollux BJ, Verberk WC, Bakker ES (2015) Native and non-native plants provide similar refuge to invertebrate prey, but less than artificial plants. PLoS ONE 10:e0124455. https://doi.org/10.1371/journal.pone.0124455

Gustafsson P, Greenberg LA, Bergman E (2014) Effects of woody debris and the supply of terrestrial invertebrates on the diet and growth of brown trout (Salmo trutta) in a boreal stream. Freshw Biol 59:2488-2501. https://doi.org/10. 1111/fwb. 12448

Heiri O, Lotter AF, Lemcke G (2001) Loss on ignition as a method for estimating organic and carbonate content in sediments: reproducibility and comparability of results.
J Paleolimnol 25:101-110. https://doi.org/10.1023/a: 1008119611481

Hodkinson ID, Jackson JK (2005) Terrestrial and aquatic invertebrates as bioindicators for environmental monitoring, with particular reference to mountain ecosystems. Environ Manag 35:649-666. https://doi.org/10.1007/ s00267-004-0211-x

Hulme PE, Pysek P, Jarosik V, Pergl J, Schaffner U, Vila M (2013) Bias and error in understanding plant invasion impacts. Trends Ecol Evol 28:212-218. https://doi.org/10. 1016/j.tree.2012.10.010

Iacarella JC, Mankiewicz PS, Ricciardi A (2015) Negative competitive effects of invasive plants change with time since invasion. Ecosphere 6:art123. https://doi.org/10. 1890/es15-00147.1

Jaeger B (2017) r2glmm: Computes R squared for mixed (multilevel) models. R package version 0.1.2. https:// CRAN.R-project.org $/$ package $=\mathrm{r} 2 \mathrm{glmm}$

Kappes H, Lay R, Topp W (2007) Changes in different trophic levels of litter-dwelling macrofauna associated with giant knotweed invasion. Ecosystems 10:734-744. https://doi. org/10.1007/s10021-007-9052-9

Keller RP, Geist J, Jeschke JM, Kühn I (2011) Invasive species in Europe: ecology, status, and policy. Environ Sci Europe 23:23. https://doi.org/10.1186/2190-4715-23-23

Kominoski JS, Shah JJF, Canhoto C, Fischer DG, Giling DP, González E, Griffiths NA, Larranaga A, LeRoy CJ, Mineau MM (2013) Forecasting functional implications of global changes in riparian plant communities. Front Ecol Environ 11:423-432. https://doi.org/10.1890/120056

Krell F-T (2004) Parataxonomy vs. taxonomy in biodiversity studies-pitfalls and applicability of 'morphospecies' sorting. Biodivers Conserv 13:795-812. https://doi.org/10. 1023/b:bioc. 0000011727.53780 .63

Kuznetsova A, Brockhoff PB, Christensen RHB (2016) lmerTest: tests in linear mixed effects models. $\mathrm{R}$ package version 2.0-33. https://CRAN.R-project.org/package= lmerTest

Lawson JR, Fryirs KA, Lenz T, Leishman MR (2015) Heterogeneous flows foster heterogeneous assemblages: relationships between functional diversity and hydrological heterogeneity in riparian plant communities. Freshw Biol 60:2208-2225. https://doi.org/10.1111/fwb.12649

Lecerf A, Patfield D, Boiche A, Riipinen MP, Chauvet E, Dobson M (2007) Stream ecosystems respond to riparian invasion by Japanese knotweed (Fallopia japonica). Can J Fish Aquat Sci 64:1273-1283. https://doi.org/10.1139/ F07-092

Lecerf A, Marie G, Kominoski JS, LeRoy CJ, Bernadet C, Swan CM (2011) Incubation time, functional litter diversity, and habitat characteristics predict litter-mixing effects on decomposition. Ecology 92:160-169. https://doi.org/10. 1890/10-0315.1

Litt AR, Cord EE, Fulbright TE, Schuster GL (2014) Effects of invasive plants on arthropods. Conserv Biol 28:1532-1549. https://doi.org/10.1111/cobi.12350

Lowe S, Browne M, Boudjelas S, De Poorter M (2000) 100 of the world's worst invasive alien species: a selection from the global invasive species database. The Invasive Species Specialist Group (ISSG), Auckland 
McCary MA, Mores R, Farfan MA, Wise DH (2016) Invasive plants have different effects on trophic structure of green and brown food webs in terrestrial ecosystems: a metaanalysis. Ecol Lett 19:328-335. https://doi.org/10.1111/ ele. 12562

Murrell C, Gerber E, Krebs C, Parepa M, Schaffner U, Bossdorf O (2011) Invasive knotweed affects native plants through allelopathy. Am J Bot 98:38-43. https://doi.org/10.3732/ ajb.1000135

Nakagawa S, Schielzeth H, O'Hara RB (2013) A general and simple method for obtaining R2 from generalized linear mixed-effects models. Methods Ecol Evol 4:133-142. https://doi.org/10.1111/j.2041-210x.2012.00261.x

Newbold T, Hudson LN, Hill SL, Contu S, Lysenko I, Senior RA, Borger L, Bennett DJ, Choimes A, Collen B, Day J, De Palma A, Diaz S, Echeverria-Londono S, Edgar MJ, Feldman A, Garon M, Harrison ML, Alhusseini T, Ingram DJ, Itescu Y, Kattge J, Kemp V, Kirkpatrick L, Kleyer M, Correia DL, Martin CD, Meiri S, Novosolov M, Pan Y, Phillips HR, Purves DW, Robinson A, Simpson J, Tuck SL, Weiher E, White HJ, Ewers RM, Mace GM, Scharlemann JP, Purvis A (2015) Global effects of land use on local terrestrial biodiversity. Nature 520:45-50. https://doi.org/10.1038/nature14324

Oksanen J, Blanchet FG, Friendly M, Kindt R, Legendre P, McGlinn D, Minchin PR, O'Hara RB, Simpson GL, Solymos P, Henry M, Stevens H, Szoecs E, Wagner H (2017) vegan: community ecology package. R package version 2.4-4. https://CRAN.R-project.org/package=vegan

Oliver I, Beattie AJ (1996) Invertebrate morphospecies as surrogates for species: a case study. Conserv Biol 10:99-109. https://doi.org/10.1046/j.1523-1739.1996.10010099.x

Pattison Z, Rumble H, Tanner RA, Jin L, Gange AC, Clements D (2016) Positive plant-soil feedbacks of the invasive Impatiens glandulifera and their effects on above-ground microbial communities. Weed Res 56:198-207. https://doi. org/10.1111/wre.12200

Pattison Z, Whytock R, Willby N (2017) Invasion legacy effects versus sediment deposition as drivers of riparian vegetation. Biol Invasions 20:1189-1198. https://doi.org/10. 1007/s10530-017-1619-6

Pejchar L, Mooney HA (2009) Invasive species, ecosystem services and human well-being. Trends Ecol Evol 24:497-504. https://doi.org/10.1016/j.tree.2009.03.016

Perrins J, Fitter A, Williamson M (1993) Population biology and rates of invasion of three introduced Impatiens species in the British Isles. J Biogeogr 20:33. https://doi.org/10.2307/ 2845737

Poland J, Clement EJ (2009) The vegetative key to the British Flora. John Poland, Southampton

Pysek P, Jarosik V, Hulme PE, Pergl J, Hejda M, Schaffner U, Vila M (2012) A global assessment of invasive plant impacts on resident species, communities and ecosystems: the interaction of impact measures, invading species' traits and environment. Glob Change Biol 18:1725-1737. https://doi.org/10.1111/j.1365-2486.2011.02636.x

R Core Team (2017) R: A language and environment for statistical computing. R Foundation for Statistical Computing, Vienna. https://www.R-project.org/

Ramey TL, Richardson JS (2017) Terrestrial invertebrates in the riparian zone: mechanisms underlying their unique diversity. Bioscience 67:808-819. https://doi.org/10.1093/ biosci/bix078

Raven PJ, Holmes NTH, Dawson FH, Everard M, Fozzard L, Rouen KJ (1998) River habitat quality. The physical character of rivers and streams in the United Kingdom and Isle of Man. River Habitat Survey Report 2. Environment Agency, Bristol

Reid AM, Hochuli DF (2007) Grassland invertebrate assemblages in managed landscapes: effect of host plant and microhabitat architecture. Austral Ecol 32:708-718. https://doi.org/10.1111/j.1442-9993.2007.01767.x

Roberts DW (2016) labdsv: Ordination and multivariate analysis for ecology. R package version 1.8-0. https://CRAN. R-project.org/package=labdsv

Rose F, O'Reilly C (2006) The wild flower key. Penguin Books Ltd, London

Ruckli R, Rusterholz H-P, Baur B (2013) Invasion of Impatiens glandulifera affects terrestrial gastropods by altering microclimate. Acta Oecol 47:16-23. https://doi.org/10. 1016/j.actao.2012.10.011

Rusterholz H-P, Salamon J-A, Ruckli R, Baur B (2014) Effects of the annual invasive plant Impatiens glandulifera on the Collembola and Acari communities in a deciduous forest. Pedobiologia 57:285-291. https://doi.org/10.1016/j. pedobi.2014.07.001

Santorufo L, Van Gestel CA, Rocco A, Maisto G (2012) Soil invertebrates as bioindicators of urban soil quality. Environ Pollut 161:57-63. https://doi.org/10.1016/j.envpol.2011. 09.042

Sax DF, Kinlan BP, Smith KF (2005) A conceptual framework for comparing species assemblages in native and exotic habitats. Oikos 108:457-464. https://doi.org/10.1111/j. 0030-1299.2005.13402.x

Schaffers AP, Sýkora KV (2000) Reliability of Ellenberg indicator values for moisture, nitrogen and soil reaction: a comparison with field measurements. J Veg Sci 11:225-244. https://doi.org/10.2307/3236802

Scherber C, Eisenhauer N, Weisser WW, Schmid B, Voigt W, Fischer M, Schulze E-D, Roscher C, Weigelt A, Allan E (2010) Bottom-up effects of plant diversity on multitrophic interactions in a biodiversity experiment. Nature 468:553. https://doi.org/10.1038/nature09492

Schirmel J, Lenze S, Katzmann D, Buchholz S (2010) Capture efficiency of pitfall traps is highly affected by sampling interval. Entomol Exp Appl 136:206-210. https://doi.org/ 10.1111/j.1570-7458.2010.01020.x

Siemens TJ, Blossey B (2007) An evaluation of mechanisms preventing growth and survival of two native species in invasive Bohemian knotweed (Fallopia $\times$ Bohemica, Polygonaceae). Am J Bot 94:776-783

Simberloff D, Martin JL, Genovesi P, Maris V, Wardle DA, Aronson J, Courchamp F, Galil B, Garcia-Berthou E, Pascal M, Pysek P, Sousa R, Tabacchi E, Vila M (2013) Impacts of biological invasions: what's what and the way forward. Trends Ecol Evol 28:58-66. https://doi.org/10. 1016/j.tree.2012.07.013

Sinnadurai P, Jones TH, Ormerod SJ (2016) Squeezed out: the consequences of riparian zone modification for specialist invertebrates. Biodivers Conserv 25:3075-3092. https:// doi.org/10.1007/s10531-016-1220-9 
Swan CM, Brown BL (2017) Metacommunity theory meets restoration: isolation may mediate how ecological communities respond to stream restoration. Ecol Appl 27:2209-2219. https://doi.org/10.1002/eap.1602

Tanner RA, Varia S, Eschen R, Wood S, Murphy ST, Gange AC (2013) Impacts of an invasive non-native annual weed, Impatiens glandulifera, on above- and below-ground invertebrate communities in the United Kingdom. PLoS ONE 8:e67271. https://doi.org/10.1371/journal.pone. 0067271

Thijs KW, Brys R, Verboven HAF, Hermy M (2011) The influence of an invasive plant species on the pollination success and reproductive output of three riparian plant species. Biol Invasions 14:355-365. https://doi.org/10. 1007/s10530-011-0067-y

Tilling S (2014) A key to the major groups of British terrestrial invertebrates, 2nd edn. Field Studies Council, London

Vacante V (2016) Handbook of mites of economic plants: identification, bio-ecology and control. CAB International, London

Van Meerbeek K, Appels L, Dewil R, Calmeyn A, Lemmens P, Muys B, Hermy M (2015) Biomass of invasive plant species as a potential feedstock for bioenergy production. Biofuels Bioprod Biorefin 9:273-282. https://doi.org/10. 1002/bbb.1539

Vila M, Espinar JL, Hejda M, Hulme PE, Jarosik V, Maron JL, Pergl J, Schaffner U, Sun Y, Pysek P (2011) Ecological impacts of invasive alien plants: a meta-analysis of their effects on species, communities and ecosystems. Ecol Lett 14:702-708. https:// doi.org/10.1111/j.1461-0248.2011.01628.x

Wardle DA, Bardgett RD, Callaway RM, Van der Putten WH (2011) Terrestrial ecosystem responses to species gains and losses. Science 332:1273-1277. https://doi.org/10.1126/ science. 1197479

Warfe DM, Barmuta LA (2004) Habitat structural complexity mediates the foraging success of multiple predator species. Oecologia 141:171-178. https://doi.org/10.1007/s00442004-1644-x

Weidenhamer JD, Callaway RM (2010) Direct and indirect effects of invasive plants on soil chemistry and ecosystem function. J Chem Ecol 36:59-69. https://doi.org/10.1007/ s10886-009-9735-0

Wickham H (2007) Reshaping data with the reshape package. J Stat Softw 21:1. https://doi.org/10.18637/jss.v021.i12

Zavaleta E (2000) The economic value of controlling an invasive shrub. AMBIO J Hum Environ 29:462-467. https:// doi.org/10.1579/0044-7447-29.8.462

Zhao Z-H, Shi P-J, Hui C, Ouyang F, Ge F, Li B-L, Freckleton R (2013) Solving the pitfalls of pitfall trapping: a two-circle method for density estimation of ground-dwelling arthropods. Methods Ecol Evol 4:865-871. https://doi.org/10. 1111/2041-210x.12083

Zuur AF, Ieno EN, Walker NF, Saveliev AA, Smith GM (2009) Mixed effects models and extensions in ecology with $\mathrm{R}$. Springer, New York

Zuur AF, Ieno EN, Elphick CS (2010) A protocol for data exploration to avoid common statistical problems. Methods Ecol Evol 1:3-14. https://doi.org/10.1111/j.2041210X.2009.00001.x

Publisher's Note Springer Nature remains neutral with regard to jurisdictional claims in published maps and institutional affiliations. 